\title{
PERAN MEDIA DALAM PEMBEAJARAN DI SD/MI
}

\author{
Suparlan \\ STIT Palapa Nusantara Lombok NTB \\ maniahparlan66@gmail.com
}

\begin{abstract}
Media words translated from Latinmedius that are fully translated 'middle', 'sponsored' or 'introduction. In Arabic, the media is the introduction or introduction of messages from the sender to the recipient of the message. Gerach \& Ely said that the media agree here is human, material, or accident that builds needs that enable people to find out, seek or seek help. Learning is an activity or a process to gain knowledge, improve skills, improve behavior, attitudes, and strengthen personality. In the context of becoming know or the process of gaining knowledge, according to conventional scientific understanding, buman contact with nature is termed experience. According to Gane, learning can determine as a process in which an organization changes its behavior as an experience.
\end{abstract}

Keywords: Media, Learning

\begin{abstract}
Abstrak : Kata media berasal dari bahasa latinmedius yang secara harfiah berarti 'tengah', 'perantara'atau 'pengantar. Dalam bahasa arab, media adalah perantara atau pengantar pesan dari pengrim kepada penerima pesan.Gerlach \& Ely mengatakan bawa media apabila di pahami secara garis besar adalah manusia, materi, atau kajadian yang membangun kondisi yang membuat siswa mampu memperoleh pengetahuan, keterampilan atau sikap. Belajar adalah sautu aktivitas atau suatu proses untuk memperoleh pengetahuan, meningkatkan keterampilan, memperbaiki prilaku, sikap, dan mengkokohkan kepribadian. Dalam konteks menjadi tahu atau proses meperoleh pengetahuan, menurut pemahaman sains konvensional, kontak manusia dengan alam diistilahkan dengan pengalaman (experience). Menurut Gane, belajar dapat didefinisikan sebagai suatu proses di mana suatu organisasi berubah prilakunya sebagai akibat pengalaman.
\end{abstract}

Kata Kunci :Media, Pembelajaran

\section{PENDAHULUAN}

Tugas bagi pengajar bukan terbatas pada mengalihkan hasil-hasil ilmu dan teknologi.Selain itu, adapun yang lebih penting yaitu menumbuhkan nila-nilai peneliti dalam diri anak untuk menunjang dari pada kemajuan Indonesia. ${ }^{1}$

Meningkatkan mutu pendidikan merupakan suatu proses yang harus dilaksankan secara terus menerus untuk mencerdaskan anak bangsa dan berbagai hal

${ }^{1}$ Conny Semiawan, dkk, Pendekatan Keterampilan Proses, (Jakarta, PT Gramedia: 1990). Hal.1

Islamika : Jurnal Keislaman dan Ilmu Pendidikan

Volume 2, Nomor 2, Juli 2020; 298-311

https:// ejournal.stitpn.ac.id/index.php/islamika 
untuk membantu terwujudnya arah agar tujuan pendidikan dapat dicapai secara efektif dan lebih efisien. Muara dari peningkatan mutu tidak lain adalah pencapaian tujuan pendidikan, yang diujudkan kemampuan yang utuh pada diri peserta didik. Proses belajar mengajar menempati posisi yang amat penting dan menentukan. Namun, perlu dicatat bahwa proses belajar mengajar merupakan suatu interaksi yang bersifat manusiawi antara pendiidk dan peserta didik yang penuh mengandung ketidakpastian. $^{2}$

Supaya tujuan pembelajaran cepat tercapai dan siswa menjadi lebih cepat memahami materi tersebut, maka seorangguru tidak hanya dituntut untuk trampil dalam menjelaskan, menyampikan materi, akan tetapi seorang guru juga harus terampil dalam membantu dan mengoprasikan media pembelajaran, sebab dengan memahami dan mengusai materi serta disertai dengan media yang baik maka proses pembelajaran akan jauh lebih bermakna dibandingkan dengan tidak diikutsertakan media dalam proses pembalajaran. Untuk itu pada artikel ini akan lebih membahan kepada meida dalam pembelajaran.

\section{Pengertian Media}

Media berasal dari bahasa latin medius yang secara harfiah berarti 'tengah', 'perantara'atau 'pengantar. Dalam bahasa arab, media adalah perantara atau pengantar pesan dari pengrim kepada penerima pesan. ${ }^{3}$ Berdasarkan pengertian di atas maka media tidak lain merupakan alat yang di gunakan oleh guru untuk memudahkan dalam proses pembelajaran dengan kata lain media yaitu sesuatu yang berupa benda yang digunakan oleh seorang guru dalam proses pembelajaran untuk mempermudah pemahaman kepada siswa.

Adapun pengertian media menurut para ahli pendidikan yaitu :Gerlach \&Ely mengatakan bawa media jika di maknai secara harpiah merupakan gabungan dari manusiam, materi dengan tujuan untuk membuat siswa mampu memperoleh pengetahuan, keterampilan atau sikap. ${ }^{4}$ Berdasarkan pengertian-pengertian di atas, maka dapat disimpulkan, media yaitu alat peraga yang digunakan oleh guru seperti

2 Zamroni, Pendidikan dan Demokrasi dalam Transisi (Prakondisi Menuju Era Globalisasi), (Jakarta, PSAP Muhammadiah : 2007), hal.237-238.

3 Azhar Arsyad, Media Pembelajaran (Jakarta, PT Rajagrafindo Persada: 2010) hal. 3

${ }^{4}$ Azhar Arsyad, Media Pembelajaran...hal3 
gambar, grafik, film, dan lain-lain yang tujuannya yaitu dapat meransang siswa didalam proses pembelajaran.

\section{Ciri-ciri Media Pembelajaran}

Gearlach \&Ely (1971) mengemukakan tiga ciri media yang merupakan petunjuk mengapa media digunakan dan apa-apa saja yang dapat dilakukan oleh media yang mungkin guru tidak mampu (kurang efisien) melakukannya.

\section{Ciri Fikasatif (Fixative Property)}

Ciri ini menggambarkan kemampuan media merekam, menyiapkan, melestarikan, dan merekonstruksi suatu pristiwa atau objek.Suatu pristiwa atau objek dapat diurut dan disusun kembali dengan media seperi fotografi, video tape, audio tape, disket computer, dan film.Dengan ciri fiksatif ini, media memunginkan suatu rekaman kejadian atau objek yang terjadi pada satu waktu tertentu ditransportasikan tanpa mengenal waktu.Ciri ini amat penting bagi guru karena kejadian-kejadian atau objek yang telah direkam atau disimpan dengan format media yang ada dapat digunakan setiap saat. ${ }^{5}$

Berdsarkan penjelasan tersebut di atas maka dapat ditarik kesimpulan bahwa ciri media fiksatif yaitu sesautu yang dapat merekam suatu kejadian atau peresitwa tertentu kemudian disamakan dan diurutkan berdasarkan kejadian peristiwa tersebut, sehingga mudah digunakan kapan saja tidak memerlukan waktu yang lama.

\section{Ciri Manipulative (Manipulative Property)}

Transpormasi suatu kejadian atau objek dimungkinkan karena media memiliki ciri manipulative.Kejadian yang memakan waktu berhari-hari dapat disajikan kepada siswa dalam waktu dua atau tiga menit dengan teknik pengambilan gambar time-lapse recording.Misalnya, bagaimana proses larva menjadi kepompong kemudian menjadi kupu-kupu dapat dipercepat dengan teknik rekaman fotografi tersebut. Di samping dapat dipercepat, suatu kejadian dapat pula diperlambat pada saat menayangkan hasil suatu rekaman video. ${ }^{6}$

5 Azhar Arsyad, Media Pembelajaran...hal. 12-13

${ }^{6}$ Azhar Arsyad, Media Pembelajaran...hal. 13 
Bedasarkan pejelasan tersebut, maka dapat ditarik sebuah kesimpulan bahwa ciri media manipulatif yaitu berperan utnuk memperlambat atau mempercepat suatu kejadian bersasarkan hasil rekaman, seperti contoh di atas tentang larva, jika tidak menggunakan media manipulative maka prosesnya akan lama, sebab larva menajdi kupu-kupu membutuhkan beberapa minggu, dengan menggunakan media manipulative maka siswa akan menjadi lebih paham dan mengerti karna prosesnya secara cepat dengan menggunakan media manipulative.

Ciri Distributive (Distributife Property)

Ciri distributive dari media memugkinkan suatu objek atau kejadian ditranspormasikan melalui ruang, dan secara bersamaan kejadian tersebut disajikan kepada sejumlah besar siswa denganstimulus pengalaman yang relative sama mengenai kejadian itu. Dewasa ini, distribusi media tidak hanya terbatas pada suatu kelas atau beberapa kelas pada sekolah-sekolah di dalam suatu wilayah tertentu, tetapi juga media itu misalnya rekaman video, dapat disebar kepenjuru tempat yang diinginkan kapan saja. ${ }^{7}$

Berdasarkan pejelasan tersebut maka media distributive merupakan media yang digunakan untuk disebarkan kepada siswa baik lewat video, audio, yang bentuknya sama walaupun disebarkan ke wilayah-wilayah penjuru di Indonesia.

\section{Jenis-jenis media}

Meida Grafis

Media grafis termasuk meida visual. Sebagaimana halnya media yang lain. Media grafis berfungsi untuk menyalurkan pesan dari sumber ke penerima pesan.Saluran yang dipakai menyangkut indera penglihatan.Pesan yang akan disampaikan dituangkan ke dalam simbol-simbol komunikasi visual. Simbol-simbol tersebut perlu dipahami benar artinya agar proses penyampaian pesan dapat berhasil dan efisien. Selain fungsi umum tersebut, secara khusus grafis berfungsi pula untuk menarik perhatian, memperjelas sajian ide, mengilunstrasikan atau menghiasi fakta yang mungkin akan cepat dilupakan atau diabaikan bila tidak digrafiskan. Selain sederhana

${ }^{7}$ Azhar arsyad, Media Pembelajaran...hal. 14 
dan murah pembuatanya media grafis termasuk media yang relative murah ditinjau dari segi biayanya. ${ }^{8}$

Media Audio

Berbeda dengan media grafis, media audio berkaitan dengan indra pendengaran. Pesan yang akan disampaikan dituangkan ke dalam lambing-lambang auditif, baik verbal (ke dalam kata-kata/bahasa lisan) maupaun non verbal. Ada beberapa jenis media dapat dikelompokkan dalam media audio, antara lain radio, alat perekam pita magnetic piringan hitam, dan laboratorium bahasa. ${ }^{9}$

Media Proyek Diam

Media proyek diam (Still Proyected Medium) mempunyai persamaan dengan media grafik dalam arti menyajikan rangsangan-rangsangan visual.Selain itu, bahanbahan grafis banyak sekali dipakai dalam media proyeksi diam perbedaan yang jelas di antara mereka adalah pada meida grafis dapat secara langsung berintraksi dengan pesan media yang bersangkutan pada media proyeksi, pesan tersebut harus diproyeksikan dengan proyektor agar dapat dilihat oleh sasaran; terlebih dahulu.Adakalnya media jenis ini disertai rekaman audio, tetapi ada pula yang hanya visual saja, seperti bingkai, film rangkai. ${ }^{10}$

\section{Fungsi Media Pembelajaran}

Fungsi utama media pembelajaran adalah sebagai alat bantu mengajar yang turut mempengaruhi iklm, kondisi, dan lingkungan belajar yang ditata dan diciptakan oleh guru. Menurut Hamalik pemakain media pembelajaran dalam proses belajar mengajar dapat membangkitkan keinginan dan minat yang baru, membangkitkan motifasi dan rangsangan kegiatan belajar dan bahkan membaca pengaruh-pengaruh psikologis terhadap siswa. Penggunaan media pembelajaran pada tahap orientasi pembelajaran akan sangat membatu keefektifan proses pembelajaran dan menyampaikan pesan dan isi pelajaran pada saat itu.Selain membangkitkan motivasi dan minat siswa, media pembelajaran juga dapat membantu siswa meningkatkan

\footnotetext{
8 Arief S. Sadiman, dkk,..hal.28-29.

9 Arief S. Sadiman, dkk,..hal.49.

${ }^{10}$ Arief S. Sadiman, dkk,...hal. 55.
} 
pemahaman, menyajikan data dengan menarik dan terpercaya, memudahkan meanfsirkan data, dan memadatkan infromasi. ${ }^{11}$

Selanjutnya Levie \&Lentz mengemukakan empat fungsi media pembelajaran, khususnya media visual, yaitu pertama fungsi atensi, yaitu menarik dan menggunakan perhatian siswa untuk berkonsentrasi kepada isi pelajaran yang berkaitan dengan media visual yang ditampilkan atau menyertai teks materi pelajaran. ${ }^{12}$ Berdasarkan penjelasan tersebut maka fungsi atensi dimana seorang guru berusaha membuat siwanya tertarik dengan pelajaran atau materi yang diajarkan dengan cara menggunakan media.

Kedua fungsi afektif, yaitu media visual dapat terlihat dari tongkat kenikmatan siswa belajar (atau membaca) teks yang bergambar.Gambar atau lambang visual dapat menggugah emosi dan sikap siswa, misalnya informasi yang menyangkut masalah sosial atau ras.Ketiga, fungsi kognitif, dimana media terlihat dari temuan-temuan penelitan yang mengungkapkan bahwa media visual atau gambar memperlancar pencapaian tujuan untuk memahami dan mengingat informasi atau pesan yang terkandung dalam media.

Keempat, fungsi kompensatoris, dimana media pembelajaran terlihat dari hasil penelitian bahwa media visual yang memberikan konteks untuk memahami teks memantu siswa yang lemah dalam membaca untuk mengorganisasikan informasi dalam teks dan mengingatkanya kembali. Dengan kata lain, media pembelajaran berfungsi untuk mengakomodasikan siswa yang lemah dan lambat menerima dan mahami isi pelajaran yang disajikan dengan teks atau disajikan secara verbal. ${ }^{13}$

Adapun menurut Kemp \& Dayton, mereka mengemukakan dampak positif dari penggunaan media sebagai bagian integral pembelajaran di kelas atau sebagai cara utama pembelajaran langsung sebagai berikut: Pertama, penyampaina pembelajaran menjadi lebih baku, setiap pembelajaran yang melihat atau mendengar penyajian melalui media menerima pesan yang sama. Meskipun para guru menafsirkan isi pelajaran dengan cara yang berbeda-beda, dengan pengguanan media ragam hasil

\footnotetext{
11 Azhar Arsyad, Media Pembelajaran...hal. 16.

${ }^{12}$ Azhar arsyad, Media Pembelajaran...hal. 16-17

${ }^{13}$ Azhar Arsyad, Media Pembelajaran...hal. 17.
} 
tafsiran itu dapat dikurangi sehingga informasi yang sama dapat disampaikan kepada siswa sebagai landasan untuk pengkajian, latihan, dan aplikasi lebih lanjut. ${ }^{14}$

Kedua, pembelajaran bisa lebih menarik. Media dapat diasosiasikan sebagai penarik perhatian dan membuat siswa tetap terjaga danmemperhatikan. Kejelasan dan keruntutan pesan, daya tarik image yang berubah-ubah, pengguanan efek khusus yang dapat menimbulkan keingintahuan menyebabakan siswa tertarik dan berfikir, yang kesemuanya menunjukkan bahwa media memiliki aspek motivasi dan meningkatkan minat.Ketiga, pembelajaran menjadi lebih interaktif dengan diterapkanya teori belajar dan prinsip-prinsip psikologis yang diterima dalam hal partisipasi siswa, umpan balik dan penguatan.Keempat, lama waktu pembelajaran yang diperlukan dapat dipersingkat karena kebanyakan media hanya memerlukan waktu singkat untuk mengantarkan pesan-pesan dan isi pelajaran dalam jumlah yang cukup banyak dan kemungkinannya dapat diserap oleh siswa. ${ }^{15}$

\section{Manfaat media dalam pembelajaran}

Sujana \&Rivai mengemukakan manfaat media pembelajaran dalam proses belajar siswa, yaitu:

a. Pembelajaran akan lebih menarik perhatian siswa sehingga data menumbuhkan motivasi belajar.

b. Bahan pembelajaran akan lebih jelas maknanya dan memungkinkanya menguasai dan mencapai tujuan pembelajaran

c. Metode mengajar akanlebih bervariasi, tidak semata-mata komunikasi verbal melalui penuturan kata-kata oleh guru, sehingga siswa tidak bosan dan guru tidak kehabisan tenaga, apalagi kalau guru mengajar pada setiap jam pelajaran.

d. Siswa dapat lebih bayak melakukan kegiatan belajar sebab tidak hanya mendengarkan uraian guru, tetapi juga aktifitas lain seperti mengamati, melakukan, mendemonstrasikan, memamerkan dan lain-lain. ${ }^{16}$

Selain hal tersebut yang di kemukakan oleh Sujana \&Rivai, manfaat media dapat di lakukan dalam dua sisi, yaitu di dalam kelas dan diluar kelas, berikut

\footnotetext{
14 Azhar Arsyad, Media Pembelajaran...hal. 21.

15 Azhar Arsyad, Media Pembelajaran...hal. 22-23

16 Azhar Arsyad, Media Pembelajaran...hal. 24-25
} 
penjelasannya.Pertama, pemanfatan media dalam situasi kelas, di mana media pembelajaran dimanfaatkan untuk menunjang tercapainya tujuan tertentu. Pemanfaatan pula dipadukan dengan proses belajar mengajar dalam situasi kelas. Dalam merencanakan pemanfaatan media itu guru harus melihat tujuan yang akan dicapai, materi pembelajaran yang mendukung tercapainya tujuan itu. Serta strategi belajar mengajar yang sesuai untuk mencapai tujuan itu.Media pembelajaran yang dipilih haruslah sesuai dengan ketiga hal itu, yang meliputi tujuan, materi, dan strategi pembelajaran.Kedua, pemanfaatan media diluar kelas, dapat dikelompokan menjadi dua yaitu pemanfaatan secara bebas dan pemanfatan secara terkontorol. ${ }^{17}$

\section{Pemilihan Media pembelajaran di SD/MI}

Media yang akan digunaakan dalam proses pembelajaran memerlukan perencanaan yang baik. Meskipun demikian, kenyataan dilapangan menunjukkan bahwa seorang guru memilih salah satu media dalam kegaitannya di kelas atas dasar pertimbangan antara lain (a) ia merasa sudah akrab dengan media itu-papan tulis atau proyektor transparansi, (b) ia merasa bahwa media yang dipilihnya dapat menggambarkan dengan lebih baik dengan dirinya sendiri, (c) media yang dipilihnya dapat menarik minat dan perhatian siswa, serta menuntunya pada penyajian yang lebih terstruktur dan terorganisasi. Pertimbangna ini diharapkan oleh guru dapat memenuhi kebutuhanya dalam mencapai tujuan yang telah ia terapkan. ${ }^{18}$

Dari segi teori belajar, berbagai kondisi dan prinsip-prinsip psikologis yang perlu mendapat pertimbangan dalam pemilihan dan menggunakan mediaadalah sebagai berikut: pertama, motivasi. Harus ada kebutuhan, minat, atau keingiann untuk belajar dari pihak siswa sebelum meminta perhatian untuk mengerjakan tugas dan latihan. Kedua, perbedaan indipudual, maksudnya siswa belajar dengan cara dan tingkat kecepatan yang berbeda-beda. Ketiga, tujuan pembelajaran, maksudnya jika siswa diberitahukan apa yang diharapkan mereka pelajari melalui mediapembelajaran itu, kesempatan untuk berhasil dalam pembelajaran semakin besar. Keempat, organisai, dimana pembelajaran akan lebih mudah jika isi dan prosedur atau keterampilan fisik 
yang akan dipelajari diatur dan diorganisasikan ke dalam urutan-urutan yang bermakna.

Kelima, persiapan sebelum belajar dimana siswa sebaiknya telah menguasai secara baik pelajaran dasar atau memiliki pengalaman yang diperlukan secara memadai yang mungkin merupakan persaratan untuk pengguanaan media dengan sukses.Keenam emosi, pembelajaran akan melibatkan emosi dan persaan pribadi serta kecakapan amat berpengaruh dan bertahan. Ketujuh partisipasi, agar pembelajaran berlangsung dengan baik, seseorang siswa harus menginternalisasi informasi, tidak sekedar diberitahukan kepada siswa.Delapan, umpan balik, hasil belajar dapat meningkat apabila secara berkala siswa diinformasikan kemajuan belajaranya.

Sembilan, penguatan (Reinforcement), apabila siswa berhasil belajar, ia didorong untuk terus belajar. Sepuluh, latihan dan pengulangan, sesautu hal baru jarang sekali dapat dipelajari secara efektif hanya dengan sekali saja maka pengetahuan atau keterampilan itu sering diulang dan dilatih dalam berbagai konteks. Sebelas, penerapan, hasil belajar yang diinginkan adalah meningkatkan kemampuan seseorag untuk menerapkan atau mentransper hasil belajar pada masalah atau situasi baru.Tanpa dapat melakukan ini, pemahaman sempurna belum dapat dikatakan dikuasai. ${ }^{19}$

\section{Kreteria Pemilihan Media Pembelajaran}

Adapun kreteria dalam memilih media pembelajaran yaitu: pertama, sesuai dengan tujuan pembelajaran yang ingin dicapai. Maksudnya media dipilih berdasarkan tujuan instruksional yang telah ditetapkan yang secara umum mengacu kepada salah satu atau gabungan dari dua atau tiga ranah kognitif, afektif, dan fsikomotorik. Tujuan ini dapat digambarkan dalam bentuk tugas yang harus dikerjakan atau dipertunjukkan oleh siswa, seperti menghapal, melakukan kegiatan yang melibatkan kegiatan fisik ataupemakaian prinisp-prinsip seperti sebab dan akibat, melakukan tugas yang melibatkan pemahaman konsep-konsep atau hubungan-hubungan perubahan, dan mengerjakan tugas-tugas yang melibatkan pemikiran padatingkatan lebih tinggi.

${ }^{19}$ Azhar Arsyad, Media Pembelajaran...hal. 72-74. 
Kedua, tepat untuk mendukung isi pelajaran yang sifatnya fakta, konsep, prinsip, atau generalissi. Media yang berbeda, misalnya filam dan grafik memerlukan simbol dan kode yang berbeda, dan oleh karena itu memerlukan proses dan keteramplan mental yang berbeda untuk memahaminya. Agar dapat membantu proses pembelajaran secara efektif, media harus selaras dan sesuai dengan kebutuhan tugas pembelajaran dan kemampuan mental siswa.

Ketiga, praktis, lues, dan bertahan. Jika tidak tersedia waktu, dana, atau sumber daya lainya untuk memproduksi, tidak perlu dipaksakan. Media yang dipiih sebaiknya dapat digunakan di manapun dan kapan pun dengan peralatan yang tersedia di sektiarnya, serta mudah dipindahkan dan dibawa kemana-mana.

Keempat, guru dapat menggunkaanya.Ini merupakaan keteria umum. Apapun media itu, guru harus mampu menggunakanya dalam proses pembelajaran. Kelima, pengelompokan sasaran. Media yang efektif untuk kelompok besar belum tentu sama efektifknya jika digunakan pada kelompok kecil atau perorangan. Keenam, mutu teknis.Pengembangan visual baik gambar maupun fotograf harus memenuhi persaratan teknis tertentu. Misalnya, visual pada silde harus jelas dan informasi atau pesan yang ditonjolkan dan ingin disampaikan tidak boleh terganggu oleh elemen lain yang berupa latar belakang. ${ }^{20}$

\section{Hubungan Media dengan Pembelajaran.}

Media dan pembelajaran sesuatu hal yang tidak bisa dipisahkan, sebab bila keduanya ini s bertolak belakangmaka proses pembelajaran tidak akan berjalan dengan baik selain itu hasil atau output dalam proses pebelajaran juga akan kurang maksimal. Contoh bila guru mengajar di kelas SD/MI tentang hujan maka dalamprose pembelajaran siswa akan di buat menghayal sebab guru tidak bisa membuat media tentang hujan, maka proses pembelajaran akan menjadi kurang meyenangkan, guru hanya bisa bercerita secara teori saja akan tetapi siswa yang masih tingkat SD/MI membutuhkan hal-hal yang kongrit. Bila ditainjau lebih mendalam maka hasil pemahaman dari proses pembelajaran yang tidak membutuhkan atau tidak menggunakan media akan jauh sekali.

20 Azhar Arsyad, MediaPembelajaran...hal. 7-76. 
Melihat dari hal-hal yang seperti itu atau penomena-penomena sekarang maka seyogyanya guru harus pandai-pandai menbuat semua media, apakah itu media cetak, elektoroik, visua atau audio, kesemuanya tersebut akan mempunyai dampak yang signipikan terhadap pemahaan sisiwa. Pemerintah sudah menyalurkan media pembelajaran ke semua sekolah mulai daritingkant yang paling bawah RA/TK sapai ke jenjang yang tinggi, kesemauna tersebut tidak lain tujuannya yaitu supaya proses pembelajaran menjadi lebih menyenangakan dan siswa menjadi lebih cepat paham.

Berlandaskan pada urain tersebut di atas, maka media dan pembelajaran tidak bisa dipisahkan satu sasma lain, dua-daunya harus berjalan bersamaan supaya proses pembelajaran menjadi lebih bermakna dan siswa-siswa menjadi lebih cepat mengerti dan meresapi materi yang diajarkan oleh guru-gurunya, selain hal tersebut materi dan media harus sesuai, sebab jika media yang diguankan dengan materi yang disampaikan tidak menyatu atau tidak nyambung maka proses pembelajaran akan menjadi kacau, contoh bila guru mengajarkan tentang air laut maka garu jangan mebuat media diluar air laut, misalnya batu, atau kompor yang menjadi medianya, itu semua tidak saling mendukung antara media dengan materi.Jadi media dan materi hasus saing mendukung dan saling beriringan.

\section{Belajar}

Istilah pembelajaran sering diidentikkan dengan pengajaran juga terlihat dalam redaksi peraturan pemerintah Repoblik Indonesia Nomor 19 Tahun 20055 tentang Standar Nasional Pendiidikan pasal 20 (tentang standar proses) dinyatakan "perencanaan proses pembelajaran meliputi silabus dan rencana pelaksanaan pembelajaran materi ajar, metode pengajaran, sumber belajar dan penilaian hasil belajar." ${ }^{21}$ Maka dapat di sumpulkan bahaw belajar dan pembelajaran meruapakan suatu kegiatan yang sama, dimana belajara merupakan hasil dari proses pembelajaran.

Belajar adalah sautu aktivitas atau suatu proses untuk memperoleh pengetahuan, meningkatkan keterampilan, memperbaiki prilaku, sikap, dan mengkokohkan kepribadian. Dalam konteks menjadi tahu atau proses meperoleh pengetahuan, menurut pemahaman sains konvensional, kontak manusia dengan alam

\section{Hal.4}

${ }^{21}$ Suryono \&Harianto, Belajar Dan Pembelajaran (Bandung, PT Remaja Rosdakarya: 2012). 
diistilahkan dengan pengalaman (experience). ${ }^{22}$ Menurut Gane, belajar dapat didefinisikan sebagai suatu proses di mana suatu organisasi berubah prilakunya sebagai akibat pengalaman.

Gage mendefinisikan belajar adalah suatu proses dimana suatu organisasi berubah prilakunya sebagai akibat dari pengalaman. Oxford Advanced Learnerr's Dictionary mendefiniskan belajar sebagai kegiatan memperoleh pengetahuan atau keterampilan melalui studi, pengalaman atau karena diajar. ${ }^{23}$ Berdasarkan beberapa pengertian tersebut, maka dapat disimpulkan bahwa belajar merupakan suatu kegiatan yang tujuannya yaitu untuk merubah prilaku manusia dari tidak tahu menjadi tahu, dari yang berprilaku tidak baik menjadi baik.

\section{Cara Memilih media Ditingakt SD/MI}

Berbicara tentang Sekolah Dasar/MI meruapakan suatu yang sangat luar biasa, sebab bila seorang mengajar di SD/MI akan menemukan sautu yagn berbeda dengan mengajar di tingkat SLTP/SLTA. Sebab di SD/MI membutuhkan energi yang banyak karena guru akan menanamkan atu memasukkan materi pembelajaran kepada siswa yang keseharianya lebih senang bermaindaripada belajar. Maka seorang guru harus berkonsentrasi penuh dan mencari caraatau teknik supaya materi yang diajarkan bisa cepat ditangkap oleh siswa.

Materi dan media meruapakan suatu hal yang tidak bisa di pisahkan, apalagi jika seorang guru mengajar di tingkat Sekolah Dasar, jika seorang guru menginginkan muridnya bisa cepat menerima materi seharusnya disertai dengan media pembelajaran walaupun media tersebuat suatu yang sangat sederhana mungkin. Guru harus pandaipandai mencari media yang sesuai dengan materi dan situasi anak sekolah dasar, untuk itu perlu diperhatikan oleh guru dalam memilih media pembelajaran. Adapun kerteria atau langkah-langkah seorang guru dalam memilih media pembelajaran ditingkat SD/MI yaitu : harus jelas, dapaat dilihat oleh sisiwa, tidak membuat siswa bosan dengan media tersebut.

${ }^{22}$ Suryono \& Harianto, belajardanPembelajaran...hal.9.

${ }^{23}$ Suryono \& Harianto, belajardampembelajaran...hal.12. 


\section{KESIMPULAN}

Kata media berasal dari bahasa latinmedius yang secara harfiah berarti 'tengah', 'perantara'atau 'pengantar. Dalam bahasa arab, media adalah perantara atau pengantar pesan dari pengrim kepada penerima pesan. ${ }^{24}$ Berdasarkan pengertian di atas maka media tidak lain merupakan alat yang di gunakan oleh guru untuk memudahkan dalam proses pembelajaran dengan kata lain media yaitu sesuatu yang berupa benda yang digunakan oleh seorang guru dalam proses pembelajaran untuk mempermudah pemahaman kepada siswa.

Adapun pengertian media menurut para ahli pendidikan yaitu : Gerlach \& Ely mengatakan bawa media apabila di pahami secara garis besar adalah manusia, materi, atau kajadian yang membangun kondisi yang membuat siswa mampu memperoleh pengetahuan, keterampilan atau sikap. AECT (association of education and communication technology, 1977) memberika batasan tentang media sebagai segala bentuk dan saluran yang digunakan untuk menyampaikan pesan atau informasi. ${ }^{25}$

Belajar adalah sautu aktivitas atau suatu proses untuk memperoleh pengetahuan, meningkatkan keterampilan, memperbaiki prilaku, sikap, dan mengkokohkan kepribadian. Dalam konteks menjadi tahu atau proses meperoleh pengetahuan, menurut pemahaman sains konvensional, kontak manusia dengan alam diistilahkan dengan pengalaman (experience). ${ }^{26}$ Menurut Gane, belajar dapat didefinisikan sebagai suatu proses di mana suatu organisasi berubah prilakunya sebagai akibat pengalaman.

Gage mendefinisikan belajar adalah suatu proses dimana suatu organisasi berubah prilakunya sebagai akibat dari pengalaman. Oxford Advanced Learnerr's Dictionary mendefiniskan belajar sebagai kegiatan memperoleh pengetahuan atau keterampilan melalui studi, pengalaman atau karena diajar. ${ }^{27}$ Berdasarkan beberapa pengertian tersebut, maka dapat disimpulkan bahwa belajar merupakan suatu kegiatan yang tujuannya yaitu untuk merubah prilaku manusia dari tidak tahu menjadi tahu, dari yang berprilaku tidak baik menjadi baik.

\footnotetext{
${ }^{24}$ Azhar Arsyad, Media Pembelajaran (Jakarta, PT Rajagrafindo Persada: 2010) hal. 3

25 Azhar Arsyad, Media Pembelajaran...hal3

${ }^{26}$ Suryono \& Harianto, belajardanPembelajaran...hal.9.

${ }^{27}$ Suryono \& Harianto, belajardampembelajaran ...hal.12.
} 
Suparlan

\section{DAFTAR PUSTAKA}

Conny Semiawan, dkk, Pendekatan Keterampilan Proses, Jakarta, PT Gramedia: 1990.

Zamroni, Pendidikan dan Demokrasi dalam Transisi (Prakondisi Menuju Era Globalisasi), Jakarta, PSAP Muhammadiah : 2007.

W. Gulo, Strategi Belajar-Mengajar, Jakarta, PT Grasindo: 2002.

Azhar Arsyad, Media Pembelajaran, Jakarta, PT Rajagrafindo Persada: 2010.

Arief S. Sadiman, dkk, Media Pendidikan Pengertian, Pengembangan Dan Pemanfaatanya, Jakarta, PT Rajagrafindo Persada, 2009.

Suryono \& Harianto, Belajar Dan Pembelajaran, Bandung, PT Remaja Rosdakarya: 2012. 